Al-Fikra: Jurnal Ilmiah Keislaman, Vol. 5, No. 1, Januari-Juni 2006

\title{
IMPLEMENTASI KLARIFIKASI NILAI DALAM PEMBELAJARAN DAN FUNGSIONALISASI ETIKA ISLAM
}

\author{
Amril M. \\ Fakultas Tarbiah dan Ilmu Keguruan UIN Suska Riau
}

\begin{abstract}
Implementation of the clarification of values in learning and the functionalization of Islamic ethics: Morality is inseparable from the development of buman existence. Perhaps, it is not excessive to say that human existence is basically morality. Developing critical and dialogical thinking towards ideas and cultures beyond the Islamic teaching in an effort to build ethical thinking and methodologies in its application in learning and developing students' moral values in particular and moral education in general seems to be a necessity which cannot be neglected. This is because the product of thinking is normally produced for the interest and consumption of the community at large who have different cultures, ways of life, ambitions and beliefs. Also, an ideology comes up as a result of the idealistic desire of the thinking itself. The application of the clarification of values and the concept of Islamic ethics (which has, from the beginning, been based on abkam alsyari'ah) has planted the moral values in the students' minds in the form of moral behaviour, honesty, and intelligence, not in the form of knowledge of morality either verbal or mechanical.
\end{abstract}

Key words: value, Morality, learning.

\section{Pendahuluan}

Pada dasarnya moralitas merupakan bagian yang tidak dapat dipisahkan dalam pengembangan eksistensialitas manusia, bahkan tidak berlebihan untuk dikatakan bahwa eksistensialitas manusia itu pada prinsipnya adalah moralitas, sedemikian rupa dari perspektif ini dapat dikatakan pula moralitas merupakan inti dari eksistensialitas manusia.

Tanpa mengecilkan eksistensialitas manusia yang lain -jika adasesungguhnya moralitas memang miliknya manusia, karena selain secara esensial telah ditakdirkan memiliki moralitas dan kemampuan untuk mengembannya, juga dituntut baik dari perspektif teologis dan sosiologis untuk mengejawantahkan moral potensial yang telah ada dalam dirinya menjadi moral aktual dalam hidup kesehariannya. Begitu eksplisitnya eksistensialitas manusia dengan moral seperti diungkap di atas menjadikan ungkapan bahwa manusia adalah makhluk bermoral, atau moral merupakan tapalbeda antara manusia dan makhluk lainnya adalah sesuatu yang mesti ditindak lanjuti.

Pendidikan, tepatnya usaha pembelajaran di sekolah, sebagai usaha sadar yang diarahkan dalam rangka meningkatkan kualitas eksistensialitas manusia, 
tentu tidak dapat dilepaskan sedikitpun dari moralitas, ${ }^{1}$ bahkan semestinya penentuan penilaian akan keberhasilan suatu pembelajaran dalam pendidikan pada materi pelajaran apa pun tidak dapat dilepaskan dari nilai moral yang didapat oleh anak didik ketika telah menyelesaikan suatu pembelajaran materi pelajaran tertentu.

Kemestian mengikutkan nilai moral dalam setiap aktivitas pembelajaran di sekolah, apalagi dalam setiap materi pelajaran memang bukan sesuatu yang baru, ${ }^{2}$ namun sayangnya fenomena pembelajaran di sekolah, pada materimateri pelajaran tertentu justru enggan mengikut sertakan nilai-nilai moral yang mesti tentunya disampaikan melalui materi pelajaran tersebut

Jadi dengan ringkas dapat dikatakan bahwa pembelajaran materi apapun dalam pendidikan mesti mengikutkan nilai-nilai moral disamping pengetahuan yang akan diberikan tersebut, bahkan yang pertama merupakan sesuatu yang sangat esensial, sekaligus sasaran utama dalam penilaian keberhasilan pembelajaran pendidikan, tanpa keberhasilan meraih yang pertama ini maka dapat dikatakan kegagalan dalam pembelajaran pendidikan di sekolah khususnya dan pendidikan dalam artian luas umumnya.

Diakui memang beragam teori telah diajukan oleh para ahli guna menumbuhkembangkan nilai-nilai moral pada anak didik di sekolah, ${ }^{3}$ namun model pembelajaran penumbuhkembangan nilai moral yang bersentuhan langsung dengan upaya pencarian langsung oleh anak didik secara cerdas,

${ }^{1}$ Keterkaitan etika atau moralitas dengan pendidikan memang tidak dapat dipisahkan, bahkan etika atau moralitas itu sendiri merupakan esensialitas pendidikan itu sendiri, sedemikian rupa keterkaitan dua entitas ini paling tidak dapat dipetakan dalam dua cakupan; substansialitas-sui generis dan metodologis-epistemic. Dimaksudkan dengan pertama bahwa esensialitas pendidikan itu sesungguhnya pada penumbuhkembangan perilaku moral dan etika, sedangkan dimaksudkan dengan kedua bahwa pencarian perumusan pendidikan dalam bentuk apapun tidak terlepaskan dari pengupayaan lahirnya perilaku moral dan etika pad anak didik. Uraian lebih lanjut untuk dua hal ini baca Amril M, Etika dan Pendidikan, (Yogyakarta: Adttya Media, 2005) dan (Pekanbaru: LSFK2P, 2005) khusus Bab II hlm. 2045. Selanjutnya ditulis Amril M, Etika....

${ }^{2}$ Tanggung jawab dan segala aktivitas pembelajaran di sekolah terhadap moral dalam telaah sejarah dapat dibaca lebih lanjut Amril M, "Moralitas Keagamaan dalam Pendidikan (Sebuah Rekonstruksi Sistem dan Metodologis di Sekolah)" Makalah disampaikan dalam Seminar Regional Musabaqab Tilawatil Qur'an Tingkat I Provinsi Jambi di Muaro Jambi pada tanggal 1 Juni 2003.

${ }^{3}$ Selain klarifikasi nilai, paling tidak ditemukan dua model pembelajaran pendidikan moral di sekolah, yakni cognitive development theory dan social learning theory. Bila pada cognitive development theory lebih berorientasi pada pembentukan pemahaman nilai-nilai moral seirama dengan tahapan-tahapan perkembangan moral yang tengah berlangsung dalam diri anak, maka pada social learning theory lebih berorientasi pada pembentukan tampilan perilaku moral senyatanya sebagai produk semisal pembelajaran imitasi atau observational learning. Untuk dua model ini baca lebih lanjut umpamanya Candee R, "Moral Educational" dalam Harold E. Mitzel (ed), Encyclopedia of Educational Research. Vol. III, (New York: The Free Press, 1977), hlm. 1249-1250. Selanjutnya ditulis Harold E. Mitzel (ed), Encyclopedia of .... Khusus untuk social learning theory dapat dibaca umpamanya Morris L. Bigge, Learning Theories For Teachers, (New York: Harper \& Row, Publisher, 1982) Bab 7 hlm. 155-166. 
dialogis dan reflektif etis terhadap problematika dan dilemma moral yang akan selalu dihadapi anak, terlihat bahwa model strategi klarifikasi nilai memiliki arti yang sangat strategis terutama untuk menumbuhkan kesadaran dari dalam diri anak itu sendiri dalam rangka penumbuhkembangkan nilai moral secara cerdas dan elegan, bukan melalui paksaan dan tekanan dari luar diri anak itu sendiri.

Tulisan ini mengetengahkan tentang apa dan bagaimana dalam menanamkan nilai-nilai moral pada anak didik melalui klarifikasi nilai dan bagaimana pula aktualitas pembelajarannya di dalam kelas. Semua uraian ini didahului dengan kupasan sisi ontologis-essensial dan fungsional-eksistensial nilai itu sendiri, sedemikian rupa menjadikan pemahaman terhadap nilai-nilai moral dalam perilaku moral anak dapat dipahami dan diupayakan dalam kehidupan keseharian anak didik di sekolah maupun di luar sekolah secara cerdas dan bertanggung jawab. Terakhir akan juga ditampilkan terapan model klarifikasi nilai pada pendidikan agama di sekolah-sekolah.

\section{Nilai dan Keberadaannya}

Tidak mudah untuk mendifinisikan tentang nilai, namun paling tidak pada tataran praxis nilai dapat disebut sebagai sesuatu yang menarik, dicari , menyenangkan, diinginkan dan disukai dalam pengertian yang baik atau berkonotasi positif. 4

Secara sederhana dapat dikatakan bahwa nilai merupakan sebuah ide atau konsep tentang sesuatu yang penting dalam kehidupan seseorang dan menjadi perhatiannya. Sebagai standar perilaku, tentunya nilai menuntut seseorang untuk melakukannya seperti telah diungkap di atas.

Konsekuensi dari pemahaman akan nilai seperti diutarakan di atas, menjadikan nilai itu secara praktis sebagai standar perilaku yang menjadikan orang berusaha untuk hidup sesuai dengan nilai-nilai yang telah diyakininya, sedemikian rupa menjadikan pula semua orang memiliki dan menginginkan nilai-nilai, sekalipun pada sebagian orang ditemukan kurang dalam pengertian tidak selamanya menyadari nilai yang dimilikinya, sehingga menjadikannya terperosok pada perilaku yang berseberangan dengan prescreptive nilai.

Kecuali itu pula, nilai pada hakikatnya juga tidak timbul dengan sendirinya, tetapi ada faktor-faktor yang menjadi prasyarat, misalnya karena manusia saling hubungan seperti yang tampak dalam pergaulannya dalam masyarakat,. atau nilai juga tidak dapat dipisahkan dari realitas dan pengetahuan yang dimiliki seseorang atau sekelompok orang. Atau boleh jadi juga suatu nilai muncul dari keinginan, dorongan, perasaan dan kebiasaan manusia yang kemudian menjadi wataknya setelah adanya penyatuan antara faktor-faktor individual, sosial yang terwujud ke dalam suatu kepribadian. ${ }^{5}$

${ }^{4}$ Henry Hazlitt, The Foundations of Morality, (Princeton: D. Van Nostrand Company, Inc., 1964), hlm. 160.

II b i d, hlm. 162. 
Sehubungan dengan pemaknaan akan nilai seperti disebutkan di atas, pada gilirannya nilai-nilai ini menjadi bagian integral dalam suatu kebudayaan sebagai bagian pengalaman yang senantiasa menjadi rujukan terhadap suatu perilaku bagi setiap individu dan masyarakat untuk menentukan suatu perilaku moral. Pendeknya, nilai akan selalu menunjukkan perkembangan dan perubahan seiring dengan kecenderungan dan sikap mental individu-individu dalam suatu masyarakat dan akan selalu dirujuk untuk menetapkan suatu perilaku bermoral atau tidak .

Sebagai standar perilaku, nilai-nilai moral membantu kita menentukan, dalam pengertian sederhana, terhadap sesuatu atau perilaku. Dalam pengertian yang lebih kompleks nilai akan membantu kita pula untuk menentukan apakah sesuatu itu perlu, baik atau buruk serta mengajak kita pula menganalisa moral reasoning dari suatu perilaku moral tertentu

Dari uraian di atas, dapat pula dipahami bahwa suatu nilai moral mencakup paling tidak tiga unsur yang tidak dapat terlepas dari nilai, yakni;

1. Nilai berhubungan dengan subjek, artinya keberadaan suatu nilai lahir dari penilaian subjek, namun ini tidak berarti menjadikan keputusan nilai bersifat subjektif dan meniadakan hal-hal lain di luar dirinya. Keputusan nilai sebagai nilai moral yang diambil oleh seseorang tidak bisa dilepaskan dari persoalan kemanusiaan dalam pengertian yang lebih luas dan keyakinan agama yang dimilikinya, nilai moral sebagai sesuatu pilihan yang terbaik dari yang baik, yang paling berharga dari yang berharga tentunya tidak akan dapat dicapai manakala keputusan nilai yang diambil oleh seseorang menafikan hal-hal lain yang sangat terkait dengan nilai moral tersebut Jadi nilai kendatipun pada awalnya bersifat subjektif, namun keputusan nilai yang dihasilkan oleh seseorang akan bersifat objektif dan universal.

2. Nilai tampil dalam konteks praktis, artinya nilai moral sangat berkaitan dengan aktivitas seseorang. Ini bukan berarti bahwa nilai berbeda dengan tindakan. Pada prinsipnya nilai moral itu merupakan tindakan moral itu sendiri begitu pula sebaliknya. Tegasnya nilai moral dan tindakan sesuatu yang tidak dapat dipisahkan, bahkan nama dari perilaku yang tampil itu sendiri adalah nilai moral itu sendiri, misalnya berperilaku sopan, jujur, adil dan sebagainya. Dalam kehidupan sehari-hari dapat dirasakan umpamanya jujur tidak hanya dipahami sebagai nilai saja, tetapi juga nama dari suatu perbuatan. Jadi nilai jujur dan perbuatan jujur merupakan satu yang tidak dapat dipisah-pisahkan. ${ }^{6}$

Sehubungan dengan paparan di atas, tentunya bila apa yang disebut sebagai nilai moral, juga tidak dapat terlepas dari karakteristik pengertian umum pada nilai seperti disebutkan di atas, umpamanya "kejujuran" kejujuran sebagai nilai manakala ia diikutkan dalam sebuah tindakan atau perilaku yang menghasilkan perilaku moral. Dengan demikian kejujuran sebagai nilai mendahului perilaku moral. Sebaliknya kejujuran kehilangan nilai moralnya

${ }^{6}$ K. Bertens, Etika, (Jakarta: Gramedia Pustaka Utama, 1994), hlm. 141 
manakala tidak diikutkan dalam suatu perilaku. Dalam pengertian seperti ini dapat pula dikatakan bahwa kejujuran sebagai nilai merupakan barometer bagi suatu perilaku nantinya apakah termasuk dalam kategori moral atau tidak bermoral, sedemikian rupa menjadikan pula posisi nilai berada pada pramoral atau mendahului moral kendatipun secara praktis antara nilai dan perilaku moral tidak dapat dipisahkan kehadirannya.

Karakterisrik nilai seperti diutarakan di atas memiliki implikasi di dalam kehidupan manusia sebagai subjek nilai, yakni:

1. Berkaitan dengan tanggung jawab manusia sebagai makhluk bebas, seperti telah disinggung di atas bahawa nilai moral sangat terkait dengan manusia, tegasnya pribadi manusia yang bertangung jawab, hal ini dikarenakan moral pada prinsipnya merupakan aktualisasi tanggung jawab manusia sebagai makhluk bebas. Hubungan nilai dengan tanggung jawab manusia dimisalkan umpamanya keadilan sebagai nilai moral, akan kehilangan nilai moralnya manakala tidak didasari oleh keputusan bebas manusia yang mesti dipertanggungjawabkannya.

2. Berkaitan dengan hati nurani, pada prinsipnya nilai moral menuntut perealisasian dalam tindakan manusia. Tuntutan seperti ini langsung atau tidak melahirkan desakan dari hati nurani manusia untuk mewujudkannya. Manusia akan merasa bersalah manakala ia melecehkan nilai-nilai yang sudah dimilikinya namun dilanggarnya, sebaliknya manusia merasa puas dan lega manakala nilai-nilai itu dapat diaktualisasikan dalam tindakan.

3. Berkaitan dengan kewajiban, pada prinsipnya nilai moral seperti nomor dua di atas akan melahirkan apa yang disebut dengan kewajiban moral Kewajiban moral sebagai hasil dari tuntutan nilai moral seperti ini pada prinsipnya merupakan sesuatu yang tidak dapat ditawar-tawar, manusia akan sealalu memiliki kecenderungan untuk melakukan nilai-nilai moral selain sesuai dengan fitrah yang telah dimilikinya sebagai makhluk bermoral, juga nilai moral tersebut merupakan substansi dari perilaku moral itu sendiri, misalnya pada perilaku jujur, nilai moral pada perilaku ini memang ada pada perilaku jujur itu sendiri, tidak di luar atau konsekuensi dari perilaku itu sendiri. ${ }^{7}$

Dari uraian di atas dapat dipahami bahwa eksistensialitas nilai moral sangat terkait dengan manusia sebagai subjek moral yang bertanggung jawab, memiliki keinginan untuk mewujudkan nilai itu atas dasar desakan kesadaran dan kemauannya, Dan terakhir adanya tuntutan kewajiban dari subjek moral untuk bersedia menunaikan nilai moral itu dalam kehidupannya sekalipun tuntutan kewajiban itu ada kalanya dating dari luar diri subjek moral.

Sedemikian rupa dapat pula dikatakan bahwa persoalan nilai moral tidak hanya pada kawasan ontologi-metaetika, atau epistemology-metodologi, tetapi juga kawasan prescriptive-implementatif. Tegasnya memahami akan nilai dan 
Al-Fikra: Jurnal Ilmiah Keislaman, Vol. 5, No. 1, Januari-Juni 2006

mengetahui akan sumber-sumber dan dasar-dasarnya sama pentingnya dengan mengimplementasikan secara sadar akan suatu nilai moral dalam perilaku senyatanya.

Khusus bagi terrealisasinya nilai-nilai moral dalam perilaku senyatanya oleh subjek moral dapat dikatakan pula bahwa internalisasi nilai yang pada prinsipnya adalah sangat bersifat individualistis, sehingga menjadikan individu secara psikologis memiliki kesadaran yang tumbuh dari dalam dirinya untuk bersedia secara ikhlas melakukan tuntutan nilai itu sendiri, kendatipun juga tidak dapat dinafikan peranan external pressure sebagai instrumen terwujudnya nilai dalam perilaku yang mana untuk yang terakhir ini hanya menjadikan individu konsumen moral.

\section{Moral dan Etika: Sebuah Penegasan dan Pendasaran Konseptual}

Dalam kehidupan sehari-hari penyepadanan istilah moral atau sopan santun, norma-norma serta etiket dengan etika secara umum sering ditemukan 8 pada hal bila dicermati cakupan makna yang terdapat pada moral, atau sopan santun dan lain-lainnya itu, memiliki perbedaan arti yang sangat mendasar dengan cakupan makna yang terdapat pada etika.

K. Bertens, ${ }^{9}$ umpamanya mengungkapkan bahwa moral itu adalah nilai-nilai dan norma-norma yang menjadi pegangan bagi seseorang atau kelompok dalam mengatur tingkah lakunya.Makna yang hampir sama untuk kata moral juga ditampilkan oleh Lorens Bagus, ${ }^{10}$ mengungkapkan antara lain, menyangkut kegiatan-kegiatan manusia yang dipandang sebagai baik/buruk, benar/salah, tepat/tidak tepat, atau menyangkut cara seseorang bertingkah laku dalam hubungan dengan orang lain.

Dari definisi diungkap di atas tercermin, bahwa kata moral itu, paling tidak memuat dua hal yang amat pokok yakni, 1) sebagai cara seseorang atau kelompok bertingkah laku dengan orang atau kelompok lain, 2) adanya norma-norma atau nilai-nilai yang menjadi dasar bagi cara bertingkah laku tersebut.

Adanya norma-norma atau nilai-nilai di dalam makna moral seperti diungkap di atas merupakan sesuatu yang mutlak. Hal ini dikarenakan norma-norma atau nilai-nilai ini di dalam moral selain sebagai standar ukur normatif bagi perilaku, sekaligus sebagai perintah bagi seseorang atau kelompok untuk berperilaku sesuai dengan norma-norma atau nilai-nilai tersebut. ${ }^{11}$

${ }^{8}$ Lihat lebih lanjut $I b i d$, hlm 3-8.

${ }^{9}$ I b i d., hlm. 9-11

10Lorens Bagus, Kamus Filsafat, (Jakarta: Gramedia Pustaka Utama), 1996, hlm. 672.

${ }^{11}$ Paul W. Taylor, "Introduction: What is Morality" dalam Paul W. Taylor (ed), Problems of Moral Philosophy an Introduction to Ethics, (California: Dickenson Publishing Company Inc. 1967), hlm . 3 
Al-Fikra: Jurnal Ilmiah Keislaman, Vol. 5, No. 1, Januari-Juni 2006

Bila makna moral seperti diungkap di atas diteropongkan pada istilah, seperti sopan santun atau etiket, maka akan terlihat bahwa makna pada dua istilah terakhir ini dapat dikelompokkan ke dalam makna moral seperti yang telah disinggung di atas. Hal ini dapat dilihat, setidaknya dari pemakaian dua kata ini yang berkaitan dengan tata aturan perilaku seseorang atau kelompok ketika berhubungan dengan orang/kelompok lain. ${ }^{12}$

Berbeda dengan muatan makna yang terdapat pada moral dan temantemannya, maka muatan pada makna etika memiliki cakupan yang jauh lebih luas dan dalam bila dibandingkan dengan muatan makna yang ditemukan pada moral seperti telah diungkap di atas. Franz Magnis-Suseno umpamanya, ${ }^{13}$ mengungkapkan bahwa etika merupakan filsafat atau pemikiran kritis dan mendasar tentang ajaran-ajaran, norma-norma, nilai-nilai serta kebiasaankebiasaan dan pandangan moral.

Pemaknaan etika seperti diungkap di atas, semakin jelas lagi bila mencermati pendapat-pendapat para ahli yang mengungkapkan secara eksplisit bahwa etika sebagai nama lain dari filsafat moral ketika etika itu dijadikan studi filosofis terhadap moral. ${ }^{14}$

Pemaknaan etika dengan filsafat moral seperti ini, sekaligus menunjukkan bahwa kajian dalam etika bukan dalam bentuk studi deskriptif sebagaimana yang dilakukan oleh para ahli ilmu-ilmu sosial seperti, sosiolog, psikolog, antropolog dan sejarahwan, akan tetapi dalam bentuk kajian kritis yang mencakup dua segi, yakni normatif dan analitik (metaetik)..$^{15}$

Dari uraian di atas terlihat jelas perbedaan makna antara moral dan lain-lainnya dengan etika. Bila pada moral dan lain-lainnya itu memiliki makna tentang bagaimana berperilaku sesuai dengan tuntutan normanorma atau nilai-nilai yang telah diakui oleh individu atau kelompok ketika bergaul dengan individu atau kelompok lainnya, maka pada etika atau filsafat moral selain seseorang dituntut dapat berperilaku sesuai dengan norma-norma atau nilai-nilai tertentu, juga dituntut mampu mengetahui dan memahami sistem, alasan-alasan dan dasar-dasar moral serta konsepkonsepnya secara rasional guna mencapai kehidupan yang lebih baik. Dengan kata lain dalam etika atau filsafat moral berperilaku moral sama pentingnya dengan mengetahui dan memahami alasan-alasan dan dasardasar norma-norma moral.

12Untuk makna etiket, lihat lebih lanjut K. Bertens, Etika, hlm. 9-11. Sedangkan makna sopan santun lihat Franz Magnis-Suseno, , Etika Dasar Masalab-Masalah Dasar Filsafat Moral, Kanisius, Yogyakarta, 1993, hlm. 14 dan 18

${ }^{13}$ Franz Magnis-Suseno, $I$ b $i$ d., hlm. 19

${ }^{14}$ Paul W. Taylor, "Introduction: What is Morality" dalam Paul W. Taylor (ed), Problems of Moral Philosophy ..., hlm. 7.

${ }^{15} \mathrm{I} b i d$. 
Jadi filsafat moral atau etika yang dimaksud adalah cakupan makna pada etika sebagai bentuk kajian kritis dan filosofis dan mendasar tentang ajaran-ajaran moral. Khusus dengan ciri filosofis ini, memagari pula, bahwa etika yang dimaksud di sini adalah bukan kajian etika dalam bentuk deskriptif, tetapi kajian etika dalam bentuk pendekatan normatif dan analitik (metaetik) sebagaimana yang telah disebutkan di muka.

Kajian etika atau filsafat moral dalam bentuk pendekatan normatif ini biasanya mencermati bentuk-bentuk sistem yang konsisten dari normanorma yang ditunjukkan validitasnya bagi semua manusia secara rasional oleh seorang filsuf moral, sedangkan pendekatan analitik (metaetik) meliputi dua aspek; penelaahan tentang konsep-konsep yang dipakai dan penelaahan mengenai logika dari alasan-alasan moral. Kedua bentuk pendekatan kajian etika seperti ini menurut para ahli tidak dapat dipisahkan. ${ }^{16}$

Dari uraian di atas dapat dikatakan pula bahwa moral dan temantemannya serta etika sangat membutuhkan akan nilai, bahkan secara tegas dapat dikatakan bahwa nilai atau norma sebagai dasar bagi perilaku moral dan etika, sedemikian rupa dapat pula dikatakan nilai dan norma merupakan pra bagi moral dan etika, baik moral dan teman-temannya maupun etika akan merujuk kepada nilai dan norma sebagai dasar pembentuk perilaku moral dan etika, sekalipun kedua kelompok ini memiliki kinerja metodologis yang sangat berbeda seperti diuraikan di atas.

\section{Nilai Moral: Sebuah Problematis dan Dilematis Psikis-Individual- Sosial Bagi Anak Didik}

Kendatipun diakui bahwa nilai-nilai moral itu pada lazimnya tumbuh dan berkembang didasarkan atas norma-norma dan aturan-aturan yang berlaku secara universal di tengah-tengah masyarakat tetapi juga mesti diakui bahwa dilemma dan prblematika moral juga tumbuh selain dari perkembangan internal psikis dan pisik yang tengah berlangsung pada diri anak, juga stimuli dinamika interaksi sosial anak dengan lingkungan di luar dirinya. Bahkan untuk yang terakhir ini pada masa tertentu lebih mendominasi penumbuhkembangan nilai-nilai moral anak dan tidak jarang akan menenggelamkan nilai-nilai moral yang telah dimiliki anak pada masa-masa sebelumnya, atau bentuk perilaku menyimpang lainnya.

Hasil kajian Pieget dan Kohberg misalnya mengungkapkan bahwa perkembangan moral itu terkait erat dengan perkembangan kognitif dan juga sebagai buah dari interaksi antara perkembangan kognitif dan pengalaman

${ }^{16}$ I $b$ i d,. Implikasi dari kajian filosofis seperti ini lebih lanjut lihat Amril M, Etika Islam, Telaah Pemikiran Raghib al-Isfahani Pustaka Pelajar, Yogyakarta, 2002, hlm. 23-24. Selanjutnya di tulis Etika Islam.... 
sosial. ${ }^{17}$ Bahkan temuan Kohberg pada penelitiannya yang lain menemukan bahwa tahapan-tahapan perkembangan moral itu sangat jelas merupakan produk interaksi anak dengan orang lain dari pada perkembangan langsung pada struktur biologis dan neorologis. ${ }^{18}$

Dari Pendapat Pieget dan Kohberg di atas mengisyaratkan bahwa interaksi sosial merupakan sesuatu yang sangat menentukan dalam pertumbuhan dan perkembangan nilai-nilai moral dalam diri anak. Interaksi sosial yang ditemukan anak kenyataannya sangat sarat dengan dinamika problematika dan dilemma moral yang secara niscaya akan sangat mudah menghancurkan nilai-nilai moral yang telah dimilikinya pada masa-masa sebelumnya.

Persoalan yang menarik dalam konteks penumbuhkembangan nilai-nilai moral bagi anak didik bahwa penumbuhkembangan nilai-nilai moral pada anak didik ternyata tidak hanya sebatas mengupayakan dan menciptakan bentuk-bentuk interaksi sosial yang sangat kondusif dan positif bagi tumbuhkembangnya nilai-nilai moral dalam kehidupan anak yang akhirnya bermuara pada perilaku moral dalam kehidupan keseharian mereka. Namun yang juga sama pentingnya, bahkan lebih penting dan memiliki arti yang amat strategis dari yang pertama, adalah menciptakan kemampuan bagi anak-anak didik secara cerdas mampu memahami dan menemukan nilai-nilai moral dalam dinamika interaksi sosialnya yang penuh dengan tantangan dan tamparan moral, terutama pada kondisi-kondisi sosial yang dinilai tidak kondusif bagi penumbuhkembangan nilai-nilai moral.

Diakui pula bahwa upaya "pengkandangan" anak didik di dalam suatu kondisi yang diset up khusus untuk penumbuhkembangan nilai-nilai moral, ternyata pada saat ini tidak lagi dapat dijadikan sebagai satu-satunya instrumen ampuh bagi keberhasilan penumbuhkembangan nilai-nilai moral pada anak didik. Hal ini dikarenakan interaksi sosial anak tidak lagi dapat ditentukan pada kondisi sosial tertentu melalui penerapan aturan-aturan hukuman yang tegas dan ketat, tetapi saat ini interaksi sosial anak telah sangat terbuka dan tidak lagi mampu sepenuhnya dibatasi oleh segala macam peraturan dan kondisi tertentu. Saat ini anak sangat mudahnya berinteraksi dengan kondisi-kondisi sosial yang boleh jadi sangat bertentangan dengan nilai-nilai moral, yang boleh jadi juga anak telah menyerap nilai-nilai amoral dengan tanpa disaringnya sebagai akibat interaksi sosialnya yang sudah sedemikian terbuka tanpa mengenal batas dan tempat.

Kecuali kondisi interaksi sosial yang sangat terrbuka seperti disebutkan di atas, diakui pula bahwa model pendidikan moral " bag of vertues" tidak pula dapat dinapikan begitu saja oleh model pembelajaran klarifikasi nilai, karena bagaiman pun juga aturan-aturan dan norma-norma nilai moral sangat

${ }^{17}$ D. Michelle Irwin, "Moral Development" dalam Harold E. Mitzel (ed), Encyclopedia of..., hlm. 1238-1239.

${ }^{18}$ I bid. 
dibutuhkan anak dalam pencarian nilai yang sedang mereka usahakan atau dapat menumbuhkan nilai-nilai moral dalam diri mereka. Akan tetapi pendidikan model. bag of vertues ini sebagaimana diterapkan selama ini dengan tanpa menyentuh dan mengetahui perkembangan kognitif anak, maka model ini akan menjadikan nilai-nilai moral yang diberikan hanya dalam bentuk pengetahuan moral yang mesti dipikulnya. Akibatnya, tidak jarang pada saat tertentu akan melahirkan pemberontakan pada diri anak, terutama setelah disulut oleh keragaman sosial yang melecehkan nilai-nilai moral yang selama ini telah diakuinya. Jadi, persoalan yang perlu diperhatikan dalam konteks dinamika perkembangan moral anak seperti hal di atas adalah bagaimana nantinya anak mampu membuat putusan-putusan moral melalui pemikirannya yang cerdas tentang nilai-nilai moral yang dihadapinya. ${ }^{19}$ Dalam konteks seperti ini lah suatu metoda epistemik yang dapat menjadikan anak mampu secara cerdas dan bertanggung jawab menentukan pilihan-pilihan nilai-nilai moral untuk kebaikan dan kebajikan dirinya, masyarakat dan Tuhannya.

Kecuali tantangan epistemologi nilai yang mesti diberikan pada anak, juga tantangan psiko-sosial anak tidak pula dapat diabaikan. Anak-anak remaja khususnya pada masa ini telah mengalami perubahan yang sangat drastis dalam perkembangan psikis mereka termasuk perkembangan moral. Turiel 20 misalnya mengatakan bahwa issu moral tidak ditentukan oleh aturan-aturan sosial atau konsensus sosial, tetapi oleh faktor-faktor yang inheren dalam hubungan sosial. Lebih lanjut dikatakannya, bahwa konsep individu tentang keyakinan distruktur oleh konsep organisasi sosial yang telah mapan, sementara pemahaman individu tentang moral didasari pada konsep kesejahteraan dan hak-hak seseorang sekaligus juga ditentukan oleh konsepkonsep keadilan.

Kendatipun terlihat bahwa pendapat di atas membedakan pemahaman antara keyakinan dan moral, namun yang tidak dapat dipungkiri bahwa nilainilai moral sangat terkait dengan interaksi sosial individu dengan lingkungannya. Bahkan peranan orang tua dan guru dalam perkembangan moral pada remaja ini tidak jarang digantikan oleh interaksi sosialnya dengan teman sebayanya. Berkoiz berdasarkan penelitiannya melaporkan bahwa pada masa remaja, alasan moral dari teman sebaya lebih menggoda, lebih meyakinkan dan lebih mendorong bagi anak dari pada alasan pada orang tua dan guru. ${ }^{21}$

Berkaitan dengan perkembangan psiko-sosial anak, John Dewey juga berpendapat bahwa anak akan menjadi lebih bermoral ketika ia telah mampu menilai situasi yang didahului oleh kemampuannya berperilaku sesuai dengan

${ }^{19}$ Amril M, Etika...., hlm. 91-92

${ }^{20}$ Tureil, E., "The Development of Concepts of Social Structure: Social Convention", dalam Harold E. Mitzel (ed), hlm. 1238

${ }^{21}$ Berkoiz, M. W., "A Critical Appraisal Of The Plus-One Convension In Moral Education" dalam. I b i d., hlm. 1240 
standar masyarakat atau kelompoknya. Begitu pula anak akan menjadi lebih rasional ketika ia telah berperilaku berdasarkan kebutuhan-kebutuhan fisiknya. ${ }^{22}$

Gejala dinamika moral yang didasarkan pada psiko-sosial dalam diri remaja juga melahirkan sikap antagonistik internal dalam diri mereka, terutama ketika berhadapan dengan dilemma moral antara larangan, otoritas dan hukuman. Dalam situasi seperti ini, remaja biasanya banyak menggunakan alasan-alasan yang lebih berorientasi pada alasan hedonistic dan needs yang berakhir biasanya dengan mudahnya anak meninggalkan nilai-nilai moral yang telah pernah dimilikinya. ${ }^{23}$

Dari paparan di atas terlihat bahwa dinamika internal psikis anak dalam aspek perkembangan moral mengalami kompleksitas yang luar biasa. Dinamika seperti ini selain didesak oleh perkembangan natural yang terjadi dalam diri anak, juga kuatnya stimulus eksternal sebagai akibat interaksi anak dengan lingkungan di luar dirinya. Keadaan seperti ini menjadikan perkembangan moral dalam diri anak cukup problematis dan dilematis. Tidak jarang anak pada masa ini akan sangat mudah melanggar nilai-nilai moral yang telah dimilikinya setelah mereka didesak oleh interaksi sosial dan kebutuhan fisiknya seperti diungkap di atas. Satu sisi pada saat ini peranan orang tua atau guru telah mulai ditinggalkan oleh anak kecuali orang tua bersedia melakukan dialog tentang isu-isu moral atau saling menghargai dan kerja sama serta mengembangkan pola berpikir induktif. ${ }^{24}$

Dari uraian di atas, yang perlu menjadi perhatian adalah bagaimana menyikapi dinamika dan dilemma moral yang terjadi pada anak dalam rangka menumbuhkembakan nilai-nilai moral dalam diri mereka. Penanaman nilainilai moral melalui bag of vertues sungguh mendapat tantangan dari anak pada masa ini, karena nilai-nilai moral yang telah dimiliki anak ketika ia memasuki interaksi sosial yang lebih terbuka dan bebas.boleh jadi dalam interaksi sosial tersebut, anak menemui nilai-nilai yang bertentangan dengan nilai-nilai moral yang telah dimilikinya.

Demikian pula halnya pada penciptaan kondisi yang kondusif untuk tumbuhkembangnya nilai-nilai moral dalam diri anak atau membentenginya dari nilai-nilai amoral melalui peraturan atau larangan yang ketat, tidak lagi sepenuhnya dapat efektif untuk menciptakan anak yang bermoral. Hal ini dikarenakan interaksi sosial sebagai elemen yang penting dalam kehidupan anak saat ini benar-benar menentukan tumbuh dan berkembangnya nilai-nilai moral dalam dirinya. Dalam konteks dinamika psiko-sosial semacam ini, anak-

${ }^{22}$ D.Michelle Irwin, "Moral Development" dalam Harold E. Mitzel (ed), Encyclopedia of ..., hlm. 1237

${ }^{23}$ Nancy, Eiseberg-Berg and Karlsson Roth., "Development of Young Children`s Prosocial Moral Judgment: A Longitudinal Follow-Up” dalam Developmental Psychology Vol. 16. No. 4. 1980, hlm. 375 .

${ }^{24}$ Boyce W. D and Jensen 1. C., Moral Reasoning: A Psyichological- philosophical Integration, University of Nebraska Press, Lincolen, 1978, hlm. 169 
anak betul-betul dipersiapkan untuk mampu menentukan dan memilih secara cerdas dan bertanggung jawab terhadap nila-niklai moral yang mesti diraihnya.

Dalam konteks seperti ini lah upaya penumbuhkembangkan kecerdasan anak terhadap pemilihan nilai-nilai moral perlu dikembangkan sehingga dalam interaksi sosialnya sekalipun dalam bentuk yang tidak menguntungkan dari sisi nilai-nilai moral, anak dengan sendirinya mampu melakukan pemilihanpemilihan nilai moral secara mandiri untuk dirinya secara bebas dan bertangung jawab dan memang untuk hal seperti ini merupakan ciri internalisasi nilai seperti telah dijelaskan pada bagaian sebelumnya..

Implementasi nyata penumbuhkembangan nilai-nilai moral seperti yang diinginkan di atas dalam pembelajaran, menjadikan klarifikasi nilai merupakan pilihan dalam menjawab dinamika psiko-sosial dalam diri anak. Tertujunya pilihan pada klarifikasi nilai seperti ini dikarenakan model pengajarannya yang memang sangat menekankan akan terwujudnya kemampuan anak untuk memilah, memilih, memahami dan bereksplorasi secara cerdas terhadap nilainilai moral yang berkembang di sekitarnya. Artinya anak diajak melakukan pilihan-pilihan nilai moral yang terbaik bagi dirinya dan masyarakatnya secara cerdas dan bertanggung jawab, sekalipun diakui bahwa model pembelajaran seperti ini kurang mementing tampilan perilaku tetapi lebih pada pemahaman moral yang sangat bermanfaat bagi moral judgment dan moral reasoning yang keduanya ini sangat mempengaruhi perilakunya nanyinya.

\section{Klarifikasi Nilai: Sebuah Strategi Penumbuhkembangan Nilai Moral Secara Rasional}

Disadari atau tidak, saat ini kita sering dihadapkan kepada berbagai pilihan nilai yang tidak jarang sangat sulit bagi seseorang untuk mengambil keputusan akan nilai tersebut, pada gilirannya tentu akan berakibat pula pada perilaku moral seseorang dalam melakoni kehidupannya. Kesulitan seperti ini semakin sangat terasa dan malah akan membingungkan bagi seseorang atau anak didik yang hidup di era yang serba cepat berubah dan beragam sebagai akibat globalisasi dan derasnya arus informasi yang tengah melanda dunia saat ini. Sesunguhnya dalam konteks kondisi seperti diutarakan di atas ini lah akan betapa pentingnya strategi penumbuhkembangan nilai pada anak didik diberikan atau diperkenalkan yang benar-benar dapat mempersiapkan anak mempu membuat pilahan dan pilihan sehingga menghasilkan nilai-nilai moral yang terbaik bagi anak didik.

Untuk dapat melahirkan anak-anak yang mampu memilah dan memilih secara cerdas terhadap nilai-nilai moral yang terbaik untuk dirinya, pendekatan klarifikasi nilai saat ini memang merupakan pilihan yang tepat untuk tujuan tersebut. Hal ini dikarenakan klarifikasi nilai itu sendiri, sebagaimana diakui oleh para pencetusnya, tidak lain merupakan semacam prosedur pada kebebasan anak untuk menunjukkan kepentingan dirinya, tujuan dan aspirasinya, keyakinan dan sikapnya dan indikator lain yang terkait dengan 
nilai. ${ }^{25}$ Lanjut Raths dan teman-temannya bahwa klarifikasi nilai itu akan membantu orang mendapatkan kejelasan tentang nilai-nilai yang boleh jadi sebelumnya membingungkannya dan ketidakkonsistennya. Dengan memanfaatkan klarifikasi nilai orang seperti ini akan mampu merefleksikan dan berfikir secara kritis dan komprehensip akan nilai-nilai yang dimilikinya dan tentang persoalan nilai-nilai yang hidup di dalam masyarakat secara keseluruhan. ${ }^{26}$ Atau boleh jadi juga memanfaatkan situasi riil kehidupan seharihari atau mengkaitkannya dengan persoalan-persoalan yang telah pernah ada dalam kehidupan. ${ }^{27}$

Dengan demikian dapat dikatakan bahwa klarifikasi nilai sebagai prosedur penumbuhkembangan nilai-niali moral pada anak didik dalam proses pembelajaran tentunya sangat menekankan pada pendekatan rasional dalam pendidikan moral guna menciptakan kemampuan untuk melahirkan keputusan-keputusan moral tentang persoalan-persoalan nilai moral atau konflik nilai-nilai moral secara cerdas dan kritis dari pada suguhan dan pemaksaan dari guru terhadap dirinya. ${ }^{28}$

Dalam praktek pembelajaran, klarifikasi nilai itu dapat diterapkan dalam bentuk penganalisaan terhadap nilai-nilai baik yang faktual maupun rasional dengan mempertimbangkan plus minus dari nilai-nilai yang ada terhadap problema nilai, sehingga nantinya semua analisa nilai ini akan membantunya membuat suatu moral judgment yang memuat nilai yang terbaik yang didapatkannya melalui kesadaran dirinya sendiri, tidak atas pakasaan dari luar dirinya. ${ }^{29}$

Dari uraian di atas terlihat bahwa pembelajaran penumbuhkembangan nilai-nilai moral melalui klarifikasi nilai sangat menekankan pada pembentukan kemampuan anak itu sendiri dengan kecerdasannya menelaah persoalanpersoalan nilai moral baik yang tengah hidup di dalam masyarakat maupun yang pernah ada di dalam kehidupan dengan menganalisa plus minus dari konsekuensi problematika nilai-nilai moral tersebut, sehingga melahirkan keputusan moral yang bertanggung jawab dan penuh kesadaran diri tanpa paksaan dari luar.

${ }^{25}$ Louis E, Raths, Merrill Harmil \& Sidney B. Simon, Values and Teacbing, Charles E. Merrill, Ohio, 1978, hlm. viii.

${ }^{26} \mathrm{I} \mathrm{bid,} \mathrm{hlm.} 4$

${ }^{27}$ Sidney B. Simon dan Polly de Sherbinin "Values Clarification: It Can Start Gently and Grow Deep" dalam Harvey F. Clarizio et all., (ed) Comtemporary Issues in Educational Psychology, Allyn and Bacon, Inc., Boston, 1977, hlm. 64.

${ }^{28}$ Lawrence Kohlberg, "The Cognitive-Developmental Approach to Moral Education" dalam I bi d, hlm. 58.

${ }^{29}$ Untuk pemahaman lebih lanjut lihat umpamanya Fritz K. Oser "Moral Education and Values Education: The Discourse Perspective" dalam Merlin C. Wittrock (ed), Handbook of Research on Teaching Mac Millan Publishing Company, New York, 1976, hlm. 932. Lihat juga Sidney B. Simon dan Polly de Sherbinin "Values Clarification: It Can Start Gently and Grow Deep" dalam I bi d, hlm. 64-70. 
Kaitannya dengan interaksi sosial anak dengan dunia lingkungannya sebagai proses penting dalam pembentukan perkembangan moral anak seperti diutarakan di atas, melalui klarifikasi nilai ini akan menjadikan anak didik memiliki sikap kritis dalam menghadapi dinamika interaksi sosialnya. Kemampuanya seperti memilih dan memilah, memahami dan mengeksplorasi dari beragam konsekuensi nilai-nilai moral yang telah didapatnya melalui klarifikasi nilai, sedemikian rupa menjadikannya mampu menetapkan mana nilai-nilai moral yang terbaik bagi kebaikan dan kehormatan dirinya. Anak akan selalu berhati-hati dan kritis terhadap nilai-nilai yang berlangsung dalam interaksi sosialnya, baik pada kondisi yang memang diciptakan untuk melahirkan nilai-nilai moral maupun pada kondisi-kondisi dilematis moral yang dihadapinya.

Dari karakteristik klarifikasi nilai yang berupaya menumbuhkan kecerdasan intelektual anak didik untuk mampu melahirkan suatu keputusan moral yang terbaik, sekalipun dalam situasi nilai moral yang sangat dilematis dan problematik, dapat dikatakan merupakan keuntungan yang sangat memungkinkan tumbuhkembangnya nilai-nilai moral dalam diri anak secara sadar dan penuh rasa tanggung jawab. Karena melalui strategi klarifikasi nilai ini, nilai-nilai moral yang diambilnya merupakan hasil diskusi kritis internal dirinya dengan beragam kemungjkinan konsekuensi yang ditimbulkan dari berbagai alternatif nilai dihadapannya. Sedemikian rupa hasil dari pencarian seperti ini akan melahirkan sikap tanggung jawab dan kesadaran diri bagi anak untuk mengaktualisasikan nilai-nilai moral hasil pilihanya dalam perilaku senyatanya. Bahkan nilai moral seperti ini akan semakin memperteguh kepercayaan dirinya untuk mengimplementasikannya dalam kehidupannya., karena nilai-nilai moral yang didapatnya bukan datang dari otoritas di luar dirinya yang adakalanya sangat represif dan dominatif, tetapi datang dari kesadaran dirinya baik terhadap nilai-nilai yang dimilikinya maupun nilai-nilai moral milik orang lain. 30

Dari kinerja klarifikasi nilai seperti diuraikan di atas, terungkap bahwa sebagai salah satu strategi penumbuhkembangan nilai-nilai moral, pada prinsipnya pendekatan seperti ini lebih menekankan pada proses pencarian nilai dari pada menelaah tentang hakekat nilai itu sendiri. Artinya penekan utama yang dilakukan melalui strategi ini adalah lebih pada pencarian dan penelahaan suatu nilai-nilai moral yang dapat menghasilkan suatu perilaku moral yang lebih baik yang dapat dipertanggung jawabkan dan rasional.

Kecuali itu, klarifikasi nilai yang juga dapat dilihat sebagai upaya metodis, selain agar nilai-nilai moral benar-benar terapresiasi dan dipahami oleh anak didik secara cerdas dan terbuka, sekaligus juga menumbuhkan sikap menerima terhadap keragaman dan perbedaan nilai di tengah-tengah masyarakat.

${ }^{30}$ Jack R. Fraenkel, How to Teach about Values: an Analytic Approach, Prentice-Hall, Inc, New Jersey, 1977, hlm. 45 
Al-Fikra: Jurnal Ilmiah Keislaman, Vol. 5, No. 1, Januari-Juni 2006

Artinyanya anak dididik untuk menyadari dan bersikap toleran bahwa akan muncul keragaman keputusan moral dalam sebuah dilemmatis moral .

Keuntungan lain yang dapat diambil melalui strategi klarifikasi nilai ini di antaranya:

1. dapat menjajaki tingkat kuantitas dan kualitas seseorang mengenai suatu nilai

2. dapat membina kesadaran terhadap suatu nilai

3. mengarahkan dan menyempurnakan nilai seseorang melalui nilai-nilai baru dari hasl kajian kritisnya

4. melatih seseorang dalam cara menilai, mengkaji sesuatu nilai maupun mengambil keputusan mengenai sesuatu nilai. ${ }^{31}$

Implementasi praktis-metodis akan strategi klarifikasi nilai seperti ini menurut Ratha dan teman-temannya 32 dapat dilakukan melalui tiga proses, yakni choosing, prizing dan acting yang dilakukan dengan tujuh kriteria aktivitas sebagai berikut:

Choosing : 1) secara bebas

2) dari pilihan

3) setelah memikirkan secara seksasama akan segala konsekuensi dari masing-masing pilihan

Prizing : 4) senang atas pilihan

5) bersedia menerima pilihan yang telah ditetapkan

Acting : 6) melakukan sesuatu atas dasar pilihan yang telah ditetapkan

7) mengulang-ulang dalam kehidupan

Selanjutnya menurut Ratha dan kawan-kawan bahwa tujuh aktivitas di atas ini lah yang disebut dengan me-nilai-kan atau dalam bahasa metodisnya disebut internalisasikan nilai kepada anak didik

Tegasnya, klarifikasi nilai merupakan strategi penanaman nilai-nilai moral dengan menempatkan anak didik sebagai subjek aktif dan kreatif dalam upaya menemukan dan mengembangkan nilai-nilai moral ke arah yang lebih baik dalam perilaku kehidupan kesehariannyanya.

Dengan klarifikasi nilai ini anak didik benar-benar ditempatkan sebagai penentu yang kreatif dalam penemuan nilai-nilai moral yang terbaik dalam kehidupannya setelah melakukan penelaahan baik dari nilai-nilai moral yang telah diakui eksistensialitasnya, maupun menemukan nilai-nilai baru terhadap dilemma moral yang tengah dihadapinya dan masyarakatnya.

Berbeda dengan pendidikan indokrinatif,33 klarifikasi nilai yang mengutamakan pendekatan rasio dalam pendidikan moral di mana anak didik

${ }^{31}$ H.Una Kartawisastra et all, Strategi Klarifikasi Nilai, Proyek Pengrembangan Pendidikan Guru (P3G), Dep. Pendd. dan Kebudayaan, Jakarta, 1980, hlm. 6.

${ }^{32}$ Louis E, Raths, Merrill Harmil \& Sidney B. Simon, V alues and Teaching, hlm. 9.

${ }^{33}$ Pendidikan nilai dalam bentuk indokrinatif biasanya tampil dalam bentuk penanaman nilai-nilai moral "bag of virtues" yang mesti dikuasai dan dipraktekkan anak tanpa mempertimbangkan kemampuan perkembangan internal psikis anak dan perkembangan 
dituntut memilah-milah dan memilih dari sekian banyak keputusan atau opini moral tentang sesuatu persoalan moral atau konflik nilai yang dirasakannya. Klarifikasi nilai tidak berusaha meneruskan lebih lanjut dari pilihan-pilihan nilai tersebut, tetapi ia berusaha menumbuhkan kesadaran diri dalan diri anak akan nilai-nilai yang dipilihnya sebagai tujuan yang ingin dicapainya. Singkatnya, definisi tujuan dari pendidikan nilai sebagai bentuk kesadaran diri yang berasal dari suatu keyakinan kebenaran dalan hal etika yang telah ditetapkan melalui klarifikasi nilai. Dalam klarifikasi nilai biasanya bukan mencari benar atau salah, tetapi mencari yang terbaik dari sekian banyak pilihan, sehingga boleh jadi akan memunculkan jawaban yang beragam dari persoalasn-persoalan moral yang diberikan oleh anak didik.

Pemanfaatan penanaman nilai-nilai moral seperti ini menjadikan guru atau orang dewasa lainnya benar-benar dituntut tidak hanya memiliki pengetahuan dan pemahaman yang luas akan nilai-nilai moral sehingga menjadikannya dapat mengarahkan pencarian akan nilai-nilai moral oleh anak didik mereka benar-benar pada nilai-nilai moral yang terbaik, juga mampu menampilkan beragam pilihan dengan berbagai konsekuensi moral yang dihasilkannya ke hadapan anak didik mereka terutama ketika anak didik mereka mengalami jalan buntu atau belum mencapai peraihan akan nilai-nilai moral yang terbaik.

\section{Desain Pembelajaran Pendidikan Nilai-Nilai Moral dalam Pendidikan}

Kuatnya peran dan fungsi sekolah seperti diungkap di atas, semestinya tidak layak lagi memunculkan semacam pertanyaan tentang pendidikan nilai itu lebih pantas dilakukan dalam keluarga atau lembaga keagamaan. ${ }^{34}$ Kendatipun jawaban atas pertanyaan seperti ini selalu berada dalam silang pendapat, namun yang jelas adalah bahwa baik sekolah maupun keluarga dan lembaga keagamaan lainnya, bahkan lembaga kemanusiaan apa saja semestinya memiliki tanggung jawab yang sama dalam penumbuhkembangan nilai-nilai moral bagi umat manusia. Tegasnya, lembaga apa saja yang bergerak bagi pengembangan eksistensilaitas dan pencerdasan anak manusia ke arah yang lebih baik dan bermartabat serta profesional secara eksplisit tidak dapat melepaskan diri dari tangung jawab pengembangan nilai-nilai moral.

historisitas anak. Aplikasinya biasanya tampil dalam bentuk formalis, otoritatif, represif dan tekstualis. Secara metodis pembelajarannya dirangkum dalam metode semisal contoh teladan yang kaku, pembiasaan makanistik, hukuman dan ganjaran dan seumpamanya.

${ }^{34}$ Fungsionalisasi lembaga-lembaga keagamaan dalam penumbuhkembangan nilai-nilai moral bagi anak didik memang sangat diharapkan, paling tidak untuk saat ini dimana lembaga pendidikan sekolah umum terindikasi "lemah" dalam upaya menumbuhkembangkan nilai-nilai moral pada anak didik mereka. Baca lebih lanjut Amril M, "Madrasah Diniyah Awaliyah :Tantangan Dan Harapan ( Membincangkan Keberadaan Dan Pembenahan MADIN Bagi Pembinaan Keagamaan Anak) " Makalah disampaikan pada Penataran Kepala Madrasah Diniyah se Provinsi Jambi tanggal 12 Agustus 2002 di Jambi. 
Tidak dapat dipisahkannya tanggung jawab bagi semua lembaga seperti ini akan penumbuhkembangan nilai-nilai moral bagi anak asuh dan anak didikannya, tidak hanya puas karena telah tertera secara juridis formal dan citacita luhur konvensional pendidikan umat manusia dari dahulu sampai sekarang dengan tegas dan jelas menginginkan adanya peningkatan kualitas aplikatif praktis akan nilai-nilai moral dalam kehidupan anak manusia dan anak didik. Bahkan lebih dari itu bahwa bukankah eksistensialitas anak manusia itu sesungguhnya berada pada kualitas aplikatif nilai-nilai moral dalam kehidupan senyata mereka. Dengan demikian dikatakan bahwa lembaga apa pun yang bergerak dalam pengembangan eksistensialitas anak manusia memiliki tanggung jawab yang sama dalam penumbuhkembangan nilai-nilai moral pada anak asuh mereka. ${ }^{35}$ Bahkan jika boleh dikatakan, keberhasilan lembaga-lembaga yang bergerak dalam pengembangan eksistensialitas anak manusia mesti diukur dari aspek peningkatan kualitas aplikatif-praktis nilai-nilai moral pada anak asuh mereka 36

Persoalaan mendasar adalah apakah ada atau tidak di antara kita yang konsen dengan pendidikan anak muda yang ingin mempelajari metodologi pendidikan nilai itu? Persoalan yang terkait untuk hal ini mencakup masyarakat dalam bentuk umum dan para pendidik khususnya apakah menginginkan anakanak didik mereka mengembangkan nilai secara masif. Mestikah anak didik dibantu secara eksplisit untuk mengeksplorasi dan mengambil beberapa kesimpulan tentang nilai? Sebenarnya tidak ada alasan bagi para pendidik untuk tidak memiliki kemampuan pengembangan pendidikan nilai. Adalah yang amat dipentingkan saat ini yakni adanya perencanaan dan disain yang sistematis terhadap strategi instruksional sekolah yang luas untuk dapat

${ }^{35}$ Untuk pendidikan Islam khususnya, penumbuhkembangan nilai-nilai moral etis ini saat ini paling tidak dalam dua kategori, yakni penumbuhkembangan nilai-nilai moral etis individual dan nilai-nilai etis sosial transformatif. Melalui dua kategoris nilai seperti ini menjadikan anak didik tidak saja shalib secara individu, tetapi juga shalih secara sosial dan sangat peka terhadap ketimpangan sosial, baik yang diciptakan secara struktural dan kultural. Baca lebih lanjut Amril M, "Pendidikan Islam: Penumbuhkembangan Perilaku Moral Etis dan Pentransformasian Masyarakat" (Sebuah Pengatar) dalam Muhmidayeli, Filsafat Pendidikan Islam, Aditiya Media, Yogyakarta dan LSFK2P, Pekanbaru, 2005, hlm. vii-xxiii.

${ }^{36}$ Besarnya tangung jawab lembaga pendidikan semisal sekolah untuk penumbuhkembangan nilai-nilai moral saat ini nyaris terabaikan terutama pada materi materi pelajaran yang diapresiasi sama sekali tidak bersentuhan dengan moral lembagalembaga, pada hal sesungguhnya materi pelajaran apa saja yang diberikan di sekolah ssecara substantif tidak dapat dipisahkan pada penumbuhkembangan nilai-nilai moral bagi anak didik mereka. Baca lebih lanjut Amril M, "Moralitas Keagamaan Dalam Pendidikan (Sebuah Rekonstruksi Metodologis-Aplikatif di Sekolah) “ dalam AL-TA LIM, Jurnal Pemikiran Islam dan Kependidikan Vol. XI, No. 15. Th. 2004, Fakultas Tarbiyah IAIN Imam Bonjol Padang, hlm. 75-90. Lihat juga Amril M, "Aktualisasi Moral-Etis 'Amr Ma 'ruf wa Naby 'an alMunkar' dalam INNOVATIO, Vol. 1, No. 4 Juli-Desember 2003, Pascasarjana IAIN STS, Jambi. 
mencapai pendidikan nilai dalam segala aspek pembelajaran di sekolah tanpa kecuali.

Dalam praktek pembelajaran di sekolah paling tidak implementasi penumbuhkembangan nilai-nilai moral itu tergambar dalam desain pembelajaran di sekolah. Pentingnya desain pembelajaran ini mengingat mengajar adalah aktivitas bertujuan. Desain pembalajaran dalam hal ini pada prinsipnya berfungsi mengarahkan aktivitas pembelajaran dapat berjalan secara efektif baik bagi guru maupun anak didik. Persoalan mendasar adalah bagaimana bentuk desain pembelajaran pendidikan nilai yang mampu memfungsionalkan "klarifikasi nilai" sebagai strategi pembelajarn nilai pada anak yang mana nilai itu sendiri cukup problematis seperti yang telah digambarkan di atas.

Paling tidak ada tiga unsur yang perlu diperhatikan dalam implementasi klarifikasi nilai yang meliputi;

1. stimulus kondisi atau kondisi faktual yang dilematis

2. perilaku pembelajaran anak didik

3. kriteria keberhasilan perilaku moral. ${ }^{37}$

Pada kondisi stimulus biasanya memuat tentang problema nilai moral yang tengah berkembang di tengah masyarakat yang menuntut solusi. Muatan pada kelompok ini benar-benar dapat merangsang anak untuk tertarik pada problema nilai-nilai moral yang berkembang pada masyarakat. Kelompok ini dikategorikan sebagai stimulus dalam pembelajaran pendidikan nilai. Oleh karena itu guru dituntut mampu menstimuli agar anak didiknya tertarik untuk memecahkan problema moral tersebut. Sebagai stimulus tentunya sangat menentukan pada tahapan berikutnya yaitu student behavior. Berhasil atau tidaknya pada tahap "behavior student" anak pada tahapan ini yang ditandai dengan ketertarikan anak didik pada problema moral tersebut.

Adapun behavior student itu sendiri merupakan aktivitas anak didik dalam memecahkan problema nilai pada tahap pertama. Pada tahap ini perilaku yang diharapkan muncul pada tahapan ini yang lazim disebut dengan cognitive process, ${ }^{38}$ misalnya dimulai dari aktivitas knowledge, comprehension, analisys, syntesism, evaluation, hingga receving, responding, valuing, organization, characterization by a value or value complex. ${ }^{39}$

${ }^{37}$ Amril M, Etika...., hlm. 110-111.

${ }^{38}$ David T. Miles dan Roger E Robinson menyebutkan bahwa cognitif process nmerupakan aktivitas mental anak didik dalam proses pembelajaran yang mesti dinyatakan secara ekspl;isit dalam tujuan instruksional yang meliputi anayzes, reviews, manipulates, generates, evaluates. Lihat lebih lanjut David T. Miles dan Roger E Robinson, "Behavioral Objectives: An Even Closser Look" dalam Harvey F. Clarizio et all., (ed) hlm. 173-174.

${ }^{39}$ Knowledge meliputi knowledge of specific, of way and mean of dealing with specifics, of universals and abtraction in a feel. Comprehension; tranlation, interpretation dan extrapolation. Analisys of element; of relationships, of organizational principles. Synthesis; production of unique commucation, of a plan or a prosed set of operations, derivation of a set of abstrac realtions. Evaluation; jutgement in terms of internal evidence, of external ceriteria. Receving; a warness, willingness to recive, controlled or selected attention. Responding; 
Tahapan ini pada prinsipnya merupakan upaya untuk mewujudkan keterampilan kognitif proses tampil dalam bentuk perilaku senyatanya (behavior), misalnya kemampuan mengevaluasi sebagai kemampuan tertinggi dalam cognitive process tampil dalam bentuk kesadaran mengontrol perhatian, kesediaan merespon dan menggeneralisasi nilai. Tampilan perilaku seperti ini tidak hanya dilihat pada kemampuan anak membuat moral jugdment baik secara verbal maupun tertulis, akan tetapi yang lebih penting lagi, terlihat pada sikap moralnya terhadap perilaku amoral dalam keseharian anak yang memang telah diketahuinya melalui cognitive process.

Perlu digarisbawahi bahwa ungkapan dalan tujuan instruksional betulbetul mencerminkan kemampuan yang bida diamati seperti kalimat "memahami" ditampilkan dalam kata-kata mengidentifikasi, mengklasifikasi, memecahkan dan memprediksi jika dibutuhkan. ${ }^{40}$ Dengan demikian aktivitas pada klarifikasi nilai sebagai pendekatan penanaman nilai betul-betul menggambarkan perilaku konkrik anak ketika mereka mendiskusikan problem nilai moral dalam pembelajarannya..

Kelompok ketiga yakni keriteria sukses. Dimaksudkan dengan kelompok ini, adalah ukuran yang jelas terhadap kemampuan siswa baik pada kelompok cognitive process maupun pada behavior. ${ }^{41}$ Pada kelompok cognitive process misalnya kemampuan anak dalam mengidentifikasi betul- betul terilihat dari kemampuannya dapat menunjukkan, menjelaskan, menganalisis dan memberikan argumentasi, mendeskripsikan, mengevaluasi dan menyimpulkan. Kita dapat melihat bagaimana corak perilaku yang ditampilkan seseorang sebagai wujud ekspresinya terhadap apa yang ia pahami dalam cognitive process yang biasanya tampak pada life style keshariannya terutama ketika ia dihadapkan pada perilaku-perilaku amoral. Tegasnya pada kelompok ketiga ini, lingkup aktivitas cognitive process maupun lingkup life style adalah merupakan kriteria kesuksesan internalisasi nilai yang mesti diperhatikan secara cermat melalui kriteria-kriteria yang sudah ditetapkan. Hanya saja bila pada pembelajaran cognitive proces itu perilakunya bersifat verbal dan tertulis, namun pada perilaku tahap ketiga ini telah terinternalisasi dalam sikap, gerak mimik dan wajah serta antusia yang selanjutnya terjelma dalam perilakunya ketika dihadapkan dengan nilai-nilai moral yang bertentangan dengan yang telah dimilikinya.

aquiescence in responding, willingness, satispaction in response. Valuing; acceptance of a value, preference for a value, commitment. Organization; conceptualization of value, organization of value system. Caracterization by a value or value complex; generalizetset, caracterization. Menurut Bloom, receving dan seterusnya termasuk domein afektif. Lihat lebih lanjut Derek Rowntree, Educational Technology in Curriculum Development, Harper \& Row, London, 1979, hlm. 31 dan 32.

${ }^{40} \mathrm{I}$ b i d., hlm. 176.

${ }^{41}$ Perilaku pada tahap ini merupakan wujud nyata dari kemampuan perilaku cognitive process. Perilaku tahap ini bisanya dikelompokkan ke dalam domain affektif oleh Bloom, atau self-actualizaton oleh Carl Roger dan life-style oleh Derek Rowntree. Baca lebih lanjut Derek Rowntree, Educational Technology in... , hlm. 29-31 
Al-Fikra: Jurnal Ilmiah Keislaman, Vol. 5, No. 1, Januari-Juni 2006

Dengan dua lingkup kemampuan ini, anak tidak lagi hanya cerdas pada lingkup kognitif tetapi juga cerdas dalam lingkup apektif, sehingga nilai moral yang teraplikasi dalam perilaku anak adalah hasil dari oleh pikirnya yang cerdas yang akhirnya melahirkan kesadaran untuk bersedia bertindak tanpa paksaan dan faktor eksternal lainnya.Tegasnya perilaku moral anak tidak lagi sematamata hanya karena kebiasaan merkanis, refresif indoktrinatif atau otoritas dari luar dirinya.

Secara garis besar aplikasi desain pembelajaran klarifikasi nilai tergambar pada diagram di bawah ini:

DISAIN PEMBELAJARAN BAGI KLARIFIKASI NILAI

\begin{tabular}{|l|l|l|}
\hline Kondisi-Stimulus & Perilaku Siswa & Kriteria Sukses \\
\hline $\begin{array}{l}\text { Deskripsi faktual } \\
\text { baik normatif } \\
\text { maupun empirik } \\
\text { problema/dilema } \\
\text { moral untuk } \\
\text { dipecahkan. }\end{array}$ & $\begin{array}{l}\text { Kemampuan perilaku } \\
\text { cognitive process: meng- } \\
\text { identifikasi, mendifinisikan, } \\
\text { memcahkan, mengevaluasi } \\
\text { dan memprediksi behavior } \\
\text { /life style; menunjukkan, } \\
\text { menjelaskan, menganalisis } \\
\text { berargumentasi, menilai } \\
\text { dan menyimpulkan. }\end{array}$ & $\begin{array}{l}\text { Perilaku konkrit } \\
\text { cognitive process } \\
\text { \& behavior/life } \\
\text { style; ekspresi } \\
\text { muka, pilihan- } \\
\text { pilihan nilai ke } \\
\text { depan dan self- } \\
\text { aktualitation }\end{array}$ \\
\hline Stimulus & $\begin{array}{l}\text { Kognitif } \\
\text { proses }\end{array}$ & Produk/ \\
\hline
\end{tabular}

\section{Implikasi Klarifikasi Nilai Dalam Pendidikan Agama: Sebuah Refleksi Evaluatif-Solusif}

Tumbuhkembangnya nilai-nilai moral dalam diri anak didik serta teraplikasnya dalam perilaku kehidupan sehari-hari mereka merupakan tujuan hakiki pendidikan agama di lembaga-lembaga pendidikan formal khususnya dan lembaga pendidikan lain umumnya. Perilaku moral yang diinginkan itu secara kategoris paling tidak terangkum dalam tujuan materi pendidikan agama di sekolah yang telah ditetapkan sebelumnya, diantaranya beriman, bertaqwa, berbudi pekerti, bertanggung jawab dan sebagainya. Namun sayangnya, langsung ataupun tidak, kinerja pendidikan agama dari aspek 
metodologis pembelajaran misalnya kurang mendukung terciptanya kemampuan anak didik untuk cerdas membuat keputusan moral dan berperilaku moral.

Tanpa bermaksud mengecilkan usaha pembelajaran pendidikan agama, ternyata dari sisi domain kognitif pembelajaran pendidikan agama, hanya lebih ke arah pembentukan kemampuan penguasaan materi yang diberikan, pada kelompok kemampuan domain kognitif, itu pun lebih terfokus pada levellevel -meminjam teori Blomm- knowledge, comprehension, aplication, agaknya sulit sampai pada level analysis, synthesis dan evaluation. Demikian pula domain afektif lebih sering capaian pembelajaran pada level receiving dan responding sedangkan pada tiga level di atasnya; valuing, organization dan characterization by value or value complex kurang mendapat perhatian. ${ }^{42}$

Akibat dari capaian pembelajaran seperti diungkap di atas, menjadikan anak didik hanya mampu mengetahui dan memahami materi-materi nilai-nilai moral yang dimuat dalam pendidikan agama, tetapi kurang mampu melakukan pencarian dan penganalisaan dari nilai-nilai moral terutama ketika dihadang oleh dilematis moral dalam kehidupan mereka atau dalam kehidupan masyarakat mereka. Selain itu, pengetahuan dan pemahaman anak akan nilainilai moral menjadi sangat terbatas, sehingga sukar bagi mereka untuk melakukan penganalisaan dan pengembangan dari nilai-nilai moral yang dimilikinya di tengah-tengah kehidupan moral yang semakin kompleks dan problematis.

Klarifikasi nilai sebagai sebuah prosedur pendidikan nilai dengan karakteristiknya pada penekanan keterampilan proses pencarian dan pengeksplorasian, penganalisisan dan pemilahan serta pemilihan dari berbagai pilihan konsekuensi nilai yang mungkin, kemudian melakukan penetapan atau membuat keputusan moral dari hasil pilihan nilai-nilai sebelumnya yang dilakukan secara cermat dan bertanggung jawab, selanjutnya menunjukkan kesedian secara sadar berperilaku dengan pilihan dari nilai-nilai moral yang telah ditetapkan, tanpa ada pakasaan dari luar kecuali didorong oleh kesadaran atas keyakinan nilai-nilai moral yang telah dimiliki, maka dapat dinilai mampu menutupi kekurangan dan kelemahan dari pembelajaran pendidikan agama yang selama ini berlangsung seperti digambarkan selintas di atas.

Namun demikian dibalik kelebihan pada pembelajaran klarifikasi nilai tidak dapat pula disangkal, bahwa kekurangan juga ditemukan pada pembelajaran model klarifikasi nilai ini.

Di antara kekurangan yang inheren pada klarifikasi nilai adalah pada sisi pemberian kebebasan yang penuh pada anak didik untuk mengeksplorasi atau memilah dan memilih serta menganalisis dari sejumlah alternatif nilai yang ingin dimiliki anak. Pada hal dari perspektif psiko-sosisal dan perkembangan moral anak pada saat ini yang sangat terpengaruh oleh interaksi sosialnya serta lebih mementingkan kepentingan-kepentingan hedonistik dan need dalam

${ }^{42}$ I b i d, hlm. 31. 
membuat keputusan moral, maka kesemuanya ini tentulah sangat membahayakan bagi anak dalam pengembangan nilai-nilai moral yang akan dimilikinya, karena secerdas dan secermat apa pun, pengklarifikasian nilai yang dilakukan anak tentu sulit melepaskan diri dari karakter perkembangan psikososial dan moral yang tengah berlangsung dalam dirinya. Terlebih lagi pada sebahagian anak yang tergolong memiliki pengetahuan nilai yang minim dalam kehidupan sebelumnya atau dalam lingkungan masyarakatnya. Bagi kelompok anak seperti ini, tentu "kemiskinan" pengetahuan nilai moral akan melahirkan pula keputusan-keputusan moral yang kurang sempurna terutama bila dibandingkan dengan kelompok anak lain yang telah memiliki pengetahuan dan nilai moral yang lebih baik.

Kekurangan lain yang juga dapat ditemukan adalah pada sisi implikasi dan konsekuensi ketika klarifikasi nilai ini diaplikasikan. Kekurangan ini di antaranya adalah bahwa sangat terbukanya kemunculan keragaman pemahaman akan nilai-nilai moral yang akan didapat anak yang juga membawa akibat pada keputusan moral yang dibuat oleh anak. Kendatipun sikap toleransi dapat ditumbuhkan oleh pembelajaran melalui klarifikasi nilai, namun sikap nihilisme dan antagonisme terhadap nilai-nilai moral, juga sangat terbuka lebar muncul dalam diri anak sebagai akibat keragaman nilai dan keputusan moral di antara mereka.

Dalam perspektif etika Islam, sesunguhnya model pembelajaran nilai moral yang menekankan pada kemampuan kecerdasan atau akal seperti pada klarifikasi nilai ini memang mendapat perhatian yang besar di kalangan para pemikir Islam.

Dalam catatan sejarah pemikiran etika Islam secara implisit ditemukan bahwa pemberdayaan kemampuan akan secara maksimal dan penguasaan akal terhadap dua kemampuan lainnya seperti daya amarah (emosi) dan daya nafsu (keinginan berlebihan) merupakan metode sentral dalam pembentukan perilaku moral. Artinya secara metodologis, dalam penumbuh-kembangan nilai-nilai moral kemudian teraplikasi dalam perilaku moral senyatanya peranan akal tidak dapat diabaikan, bahkan untuk mencapai kehidupan moral yang lebih tinggi seperti sa'adah, malakiyan rabbaniyan atau insān kamil merupakan produk maksimal kerja akal dalam memfungsikan potensi-potensi naturalnya. ${ }^{43}$

Begitu pula dalam pencarian dan pengeksplorasian, pemilihan dan pemilahan dari berbagai pilihanan nilai-nilai moral sebagai konsekuensi dari suatu perilaku, dalam perspektif etika Islam segala usaha seperti ini tetap dilandasi pada kriteria yang telah ditetapkan, yakni bermanfaat, memberi

${ }^{43}$ Teori Etika Islam berkenaan penumbuhkembangan perilaku moral melalui pemberdayaan maksimalisasi fungsionalitas akal dan menunaikan Ibadah-Ibadah Fardhu Baca lebih lanjut umpamanya Amril M, "Self-Purification Dalam Pemikiran Etika Islam (Suatu Telaah Atas Pemikiran Etika Raghib al-Isfahani dan Refleksinya dalam engatasi Qua Vadis Modernitas" dalam Al-Fikra, Vol. 2. No. 1 Januari 2003, Pascasarjana IAIN SUSQA Pekanbaru, hlm. 43- 59. 
kebaikan dan kenyamanan, sekalipun nilai moral yang didapat melalui pengkalkulasian kualitas dan kunatitas dari kriteria ini terkelompokkan pada khair li ghairibi (baik kondisional). ${ }^{44}$ Dengan demikian dari perspektif etika Islam, upaya pencarian nilai-nilai moral oleh akal secara cesdas tetap didasari pada tiga kriteria, sedemikian rupa dalam pembelajarannya tentu pengkalkulasian baik kualitatif maupun kuantitatif dari tiga kriteria nilai moral ini, terus diperhitungkan ketika menelaah konsekuensi dari berbagai pilihan yang melahirkan nilai-nilai moral sebagai dasar pembuatan keputusan moral. Patokan seperti ini tentu secara tegas akan membendung masuknya keinginan hedonistik dan kebutuhan needs ketika anak membuat keputusan moralnya. Melalui penelaahan nilai-nilai moral dari berbagai pilihan atas konsekuensikonsekuensi nilai yang didatangkanya dengan tetap berpijak pada tiga kriteria nilai moral baik, menjadikan pilihan nilai moral yang akan didapatkan oleh anak didik merupakan nilai-nilai moral yang jauh lebih baik dari pada capaian yang dihasilkan melalui klarifikasi nilai.

Kecuali semua itu bahwa pengupayaan dalam bentuk apapun untuk menentukan nilai-nilai moral, ajaran-ajaran agama, terutama yang terkelompokkan dalam abkam al-syari ah 45 menjadi dasar dan diprioritaskan dalam penumbuhkembangan nilai-nilai moral dalam diri seseorang, termasuk anak didik tentunya. Hal ini dikarenakan abkam al-syariah selain secara fundamental dapat menumbuhkembangkan perilaku moral, juga ajaran-ajaran agama menjadi rujukan dalam upaya pencarian nilai-nilai moral. Tegasnya dapat pula dikatakan bahwa ajaran-ajaran fundamental agama mesti mendahului dan menjadi dasar dalam penumbuhkembangan nilai-nilai moral pada anak.

Dari uraian di atas terlihat bahwa konsep penumbuhkembangan nilainilai moral dalam etika Islam sangat memungkinkan dapat menutupi dan mengatasi kekurangan dari model pembelajaran nilai melalui klarifikasi nilai, bahkan lebih dari itu sesungguhnya dapat dijadikan dasar dan acuan ketika model pembelajaran nilai melalui klarifikasi nilai ini diterapkan Karena dengan mendasari dan mengacu pada konsep etika Islam seperti dipaparkan di atas, maka kelemahan baik langsung maupun tidak langsung yang melekat pada pembelajaran melalui klarifikasi nilai seperti kebebasan tanpa batas,

${ }^{44}$ Dalam persektif Etika Islam nilai moral yang baik itu dikelompokkan dikelompokkan dalam dua kategori; khair li zatibi; nilai moral baik di dalam baik itu sendiri, bukan sebagai akibat yang ditimbulkannya mendatangkan kebaikan dan sebagainya sedangkan khair li ghairibi; nilai moral baiknya ditentukan oleh konsekuensi yang didatangkannya dengan ukuran tiga kriteria, memberi manfaat, kebaikan dan kenyamanan. Untuk kelompok pertama biasanya nilai moral baiknya bersifat intrinsik sedangkan kelompok kedua bersifat ekstrinsik. Lihat lebih lanjut Amril M, Etika Islam...., hlm. 216-218.

45 Abkam al-Syari a adalah ibadah-ibadah fardhu yang telah ditentukan dengan batasan-batasan yang telah ditetapkan, meninggalkannya termasuk zalim yang disengaja. Lihat lebih lanjut Amril M, Etika Islam ... I b i d,hlm. 93-94 
Al-Fikra: Jurnal Ilmiah Keislaman, Vol. 5, No. 1, Januari-Juni 2006

terbukanya nihilisme dan antagonitisisme nilai-nilai moral serta kemiskinan nilai moral yang berakibat kedangkalan penganalisiaan terhadap berbagai konsekuensi dari dilematis moral, akan tertanggulangi dan terbendung.

\section{Kesimpulan}

Selalu mengembangkan pemikiran kritis dan dialektik terhadap pemikiran-pemikiran dari luar Islam dan budaya-budaya dari luar dalam upaya membangun pemikiran etika dan metodologi pengaplikasiannya pada pembelajaran penumbuhkembangan nilai-nilai moral anak didik kususnya dan pendidikan moral umumnya, merupakan suatu kemestian yang tidak dapat ditawar dan diabaikan. Alasanya, selain suatu hasil pemikiran lazimnya diproduk untuk kepentingan dan kosumsi suatu masyarakat dan kelompok tetertu yang nota bene memiliki perbedaan yang mendasar, seperti budaya, pandangan hidup dan cita-cita serta keyakinan, juga lazimnya suatu pemikiran lahir dari keinginan idealis pemikran itu sendiri atau aliran pemikiran yang mendasarinya.

Klarifikasi nilai dengan pendasaran dan merujuk pada etika Islam menjadikan pendekatan pembelajaran penumbuhkembangan nilai-nilai moral ini menjadi kompatibel bagi pengembangan perilaku moral anak yang betulbetul dapat melahirkan perilaku moral yang diinginkan. Bukan perilaku moral yang lahir dari upaya penelaahan oleh akal manusia secara bebas dan tanpa adanya kriteria ideal dalam konteks moralitas.

Khusus bagi pendidikan agama di sekolah, penerapan melalui klarifikasi nilai dengan pendasaran pada etika Islam, mejadikan strategi pembelajaran penumbuhkembangan nilai-nilai moral seperti ini, secara niscaya akan sangat memungkinkan lahirnya perilaku-perilaku moral yang berakar dari kesadaran anak didik itu sendiri serta memiliki kecerdasan pula dalam menganalisis segala problematika dan dilemmatika nilai-nilai moral yang sangat mungkin dihadapi anak dalam kesehariannya. Dengan ungkapan lain bahwa melalui penerapan klarifikasi nilai plus konsep etika Islam yang sejak dari awalnya sangat mengupayakan keterarahan dan pendasaran pada abkam al-syari a menjadikan penumbuhkembangan nilai-nilai moral dalam diri anak bukan dalam bentuk pengetahuan moral dalam bentuk verbalistik dan mekanistik sebagaimana teramati selama ini, tetapi merupakan perilaku moral yang ikhlas, jujur dan cerdas serta menjadikan anak didik cerdas dalam mengatasi problematika moral dihadapannya untuk segera dipecahkannya.

\section{Bibliografi}

Al-Isfahani, Raghib, al-Zari`a ila Makarim al-Syari`a, Abu Yazid al-`Ajami (ed), (Kairo: Dar al-Wafa`, 1987)

Bagus, Lorens, Kamus Filsafat, (Jakarta: Gramedia Pustaka Utama, 1996) 
Al-Fikra: Jurnal Ilmiah Keislaman, Vol. 5, No. 1, Januari-Juni 2006

Bertens, K, Etika, (Jakarta: Gramedia Pustaka Utama, 1994)

Bigge, Morris L., Learning Theories For Teachers, (New York: Harper \& Row Publisher, 1982)

Boyce W. D and Jensen 1. C., Moral Reasoning: A Psyichological-Philosophical Integration, (Lincolen: University of Nebraska Press, 1978)

E,Tureil, "The Development of Concepts of Social Structure: Social Convention", dalam Harold E. Mitzel (ed),

Eiseberg-Berg, Nancy, and Karlsson Roth., "Development of Young Children`s Prosocial Moral Judgment: A Longitudinal Follow-Up" dalam Developmental Psychology Vol. 16. No. 4. 1980.

Fraenkel, Jack R, How to Teach about Values: an Analytic Approach, (New Jersey: Prentice-Hall Inc, 1977).

Hazlitt, Henry, The Foundations of Morality, (Princeton: D. Van Nostrand Company Inc, 1964).

Irwin, D. Michelle, "Moral Development" dalam Harold E. Mitzel (ed), Encyclopedia of Educational Research. Vol. III, (New York: The Free Press, 1977).

Kartawisastra, H. Una et all, Strategi Klarifikasi Nilai, Proyek Pengembangan Pendidikan Guru (P3G), (Jakarta: Dep. Pendd. dan Kebudayaan, 1980).

Kolberg, Lawrence "The Cognitive-Developmental Approach to Moral Education"

M, Amril, Etika dan Pendidikan, (Yogyakarta: Adttya Media, dan Pekanbaru: LSFK2P, 2005)

.’Pendidikan Islam: Penumbuhkembangan Perilaku Moral Etis dan Pentransformasian Masyarakat" (Sebuah Pengatar) dalam Muhmidayeli, Filsafat Pendidikan Islam, (Yogyakarta: Adttya Media, dan Pekanbaru: LSFK2P, 2005)

."Moralitas Keagamaan Dalam Pendidikan (Sebuah Rekonstruksi Metodologis-Aplikatif di Sekolah)“ dalam AL-TA'LIM, Jurnal Pemikiran Islam dan Kependidikan Vol. XI, No. 15. Th. 2004, Fakultas Tarbiyah IAIN Imam Bonjol Padang.

, 'Aktualisasi Moral-Etis 'Amar Ma 'ruf wa Naby 'an al-Munkar' dalam Pendidikan (Sebuah Rekonstruksi Aplikatif-Metodis” dalam 
Al-Fikra: Jurnal Ilmiah Keislaman, Vol. 5, No. 1, Januari-Juni 2006

INNOVATIO, Vol. 3, No.4 Juli-Desember 2003, Program Pascasarjana IAIN STS, Jambi

--------, "Self-Purification Dalam Pemikiran Etika Islam (Suatu Telaah Atas Pemikiran Etika Raghib al-Isfahani dan Refleksinya dalam engatasi Qua Vadis Modernitas" dalam Al-Fikra, Vol. 2. No. 1 Januari 2003, Pascasarjana IAIN SUSQA Pekanbaru.

, Etika Islam, Telaah Pemikiran Raghib al-Isfahani, (Yogyakarta: Pustaka Pelajar, 2002)

,Madrasah Diniyah Awaliyah :Tantangan Dan Harapan Membincangkan Keberadaan Dan Pembenahan MADIN Bagi Pembinaan Keagamaan Anak) " Makalah disampaikan pada Penataran Kepala Madrasah Diniyah se Provinsi Jambi tanggal 12 Agustus 2002 di Jambi.

Magnis-Suseno, Franz, Etika Dasar Masalab-Masalah Dasar Filsafat Moral, (Yogyakarta: Kanisius, 1993).

Miles, David T dan Roger E Robinson, "Behavioral Objectives: An Even Closser Look" dalam Harvey F. Clarizio et all., (ed) Comtemporary Issues in Educational Psychology, (Boston: Allyn and Bacon, Inc., 1977)

Oser, Fritz K, "Moral Education and Values Education: The Discourse Perspective" dalam Merlin C. Wittrock (ed), Handbook of Research on Teaching (New York: Mac Millan Publishing Company, 1976).

Rowntree, Derek, Educational Technology in Curriculum Development, (London: Harper \& Row, 1979)

R Candee, "Moral Educational " dalam Harold E. Mitzel (ed), Encyclopedia of Educational Research. Vol. III, (New York: The Free Press, 1977)

Raths, Louis E, Merrill Harmil \& Sidney B. Simon, Values and Teaching, (Ohio: Charles E. Merrill, 1978)

Simon, Sidney B. dan Polly de Sherbinin "Values Clarification: It Can Start Gently and Grow Deep" dalam Harvey F. Clarizio et all., (ed)

Taylor, Paul W, "Introduction: What is Morality" dalam Paul W. Taylor (ed), Problems of Moral Philosophy an Introduction to Ethics, (California: Dickenson Publishing Company Inc., 1967).

W. Berkoiz, M., “A Critical Appraisal Of The Plus-One Convension In Moral Education" dalam. Harold E. Mitzel (ed), Encyclopedia of Educational Research. Vol. III, (New York: The Free Press, 1977). 